\title{
CLIPPING THE STORK'S WINGS: COMMERCIAL SURROGACY REGULATION AND ITS IMPACT ON FERTILITY TOURISM
}

\author{
Katherine Voskoboynik ${ }^{*}$ \\ Introduction
}

In 2007, fertility issues led Crystal Travis and her husband, Colin McRae, to pursue surrogacy. ${ }^{1}$ However, in the United States, the cost of paying someone to carry their baby ranged from $\$ 120,000$ to $\$ 170,000 .{ }^{2}$ Unable to afford the hefty price, the couple explored cheaper options and embarked on a journey to India, where surrogacy costs between $\$ 20,000$ and $\$ 60,000 .{ }^{3}$ Nine months later, the couple's son Mark was born and they became parents at "a fraction" of what the cost would have been in the United States. ${ }^{4}$

Conversely, Paulo and João of Portugal, where surrogacy is prohibited, traveled to the United States to welcome their son into the world..$^{5}$ A surrogate mother in Pennsylvania carried their baby. ${ }^{6}$ Paulo and João are part of the "increasing flow" of affluent international couples who come to the United States to escape their home countries' restrictive surrogacy laws. ${ }^{7}$

\footnotetext{
* B.A. DePauw University, 2013; J.D. Indiana University Robert H. McKinney School of Law, expected May 2016. The author gratefully acknowledges her family, Jason Schwartz, and Michele Jackson, Esq. for their support and assistance. The author also thanks the members of Volume XXVI of the Indiana International and Comparative Law Review for their diligence and expertise.

${ }^{1}$ Nicole Grether \& Adam May, Going Global for a Family: Why International Surrogacy is Booming, Al JazeeraAmerica,May12,2014,http://america.aljazeera.com/watch/shows/america-tonight/articles/2014/5/12/goingglobal-forafamilywhyinternationalsurrogacyisbooming.html[http://perma.cc/UN6J-RXYN].

${ }^{2} I d$.

${ }^{3} I d$.

${ }^{4} I d$.

5 Tamar Lewin, Coming to U.S. for Baby, and Womb to Carry It, New York Times, July 5, 2014, http://www.nytimes.com/2014/07/06/us/foreign-couples-heading-to-america-for-surrogatepregnancies.html[http://perma.cc/38N6-BWAY].

${ }^{6} \mathrm{Id}$.

${ }^{7} I d$.
} 
Technological advancements have paved the way for individuals living with infertility to realize their dream of creating a family. ${ }^{8}$ In vitro fertilization ("IVF") has become more accessible and affordable, thus creating multiple roads to parenthood for those with reproductive difficulties. ${ }^{9}$ One of these paths is to have babies through surrogacy, which is becoming increasingly common. ${ }^{10}$ In an era of globalization, individuals seeking to become parents through surrogacy are able to travel to other countries to achieve this goal. ${ }^{11}$ Individuals whose countries of origin restrict or forbid surrogacy often use this route to become parents. ${ }^{12}$ Additionally, exorbitant costs compel potential parents to seek cheaper surrogacy alternatives elsewhere. ${ }^{13}$

The recent advances in assisted reproductive technology (“ART") have prompted states and countries to update their laws to reflect this growing field. ${ }^{14}$ Commercial gestational surrogacy is currently legal in the following countries: ${ }^{15}$ The United States, India, Ukraine, Russia, and Mexico. ${ }^{16}$ Some of these countries are currently experiencing a great deal of legislative movement, and others have recently enacted changes in their surrogacy laws. ${ }^{17}$

\footnotetext{
${ }^{8}$ Vanessa S. Browne-Barbour, Bartering For Babies: Are Preconception Agreements in the Best Interests of Children? 26 Whittier L. Rev. 429, 434 (2004).

${ }^{9}$ April L. Cherry, The Rise of the Reproductive Brothel in the Global Economy: Some Thoughts on Reproductive Tourism, Autonomy, and Justice, 17 U.PA. J.L. \& SoC. CHANGE 257, 260 (2014).

${ }^{10}$ Sarah Mortazavi, Note, It Takes a Village to Make a Child: Creating Guidelines for International Surrogacy, 100 GEO. L.J. 2249, 2250 (2012).

${ }^{11}$ Cherry, supra note 9, at 260.

${ }^{12}$ Id. at 261.

${ }^{13} I d$.

${ }^{14}$ Ailis L. Burpee, Note, Momma Drama: A Study of How Canada's National Regulation of Surrogacy Compares to Australia's Independent State Regulation of Surrogacy, 37 GA. J. INT'L \& COMP. L. 305, 310 (2009).

${ }^{15}$ Thailand was originally a part of this list. However, in February 2015, Thailand's legislature enacted a law banning commercial surrogacy and forbidding foreigners from pursuing surrogacy in Thailand. Thailand provides an essential example of the intersection of fertility tourism and commercial surrogacy, and will remain one of the countries examined in this Note.

${ }^{16}$ Helier Cheung, Surrogate Babies: Where can you have them, and is it legal?, BBC News, Aug. 6, 2014, http://www.bbc.com/news/world-28679020. [http://perma.cc/ME3R-JBWR].

${ }^{17}$ Burpee, supra note 14, at 310.
} 
This Note explores the following in the context of the countries that allow commercial gestational surrogacy (the United States, India, Ukraine, Russia, Mexico, and until recently, Thailand ${ }^{18}$ ): I) the connection between fertility tourism and commercial surrogacy; II) the legal issues generated by the intersection of fertility tourism and commercial surrogacy; and III) the ethical issues generated by the intersection of fertility tourism and commercial surrogacy. This Note ultimately observes that stringent commercial surrogacy regulation unintentionally breeds deregulation. As laws become stricter, individuals flock to dangerously unregulated countries to pursue surrogacy, promulgating the anarchic environment the laws sought to prevent. This Note concludes with an evaluation of the solutions proposed by scholars and practitioners to the aforementioned issue.

\section{The Connection Between Fertility Tourism and Surrogacy}

\section{A. Definitions}

\section{Fertility Tourism}

Fertility tourism is described as "the act of traveling abroad to take advantage of assisted reproductive technologies." ${ }^{\prime 19}$ This recent phenomenon emerged as a byproduct of technological advances in assisted reproduction. ${ }^{20}$ In the late 1970s, industrialized countries began to offer services such as egg and sperm donation, third-party gamete transfer, and in vitro fertilization. ${ }^{21}$ One of the more rapidly evolving areas affected by these scientific developments is surrogacy. ${ }^{22}$

\footnotetext{
${ }^{18}$ The ban is to be enforced by June 2015.. Thai Parliament Bans Surrogacy for Foreigners, France 24, February 20, 2015, http://www.france24.com/en/20150220-thailand-parliament-bans-surrogacy-foreigners-gammy/. [http://perma.cc/M9CM-XQBR].

${ }^{19}$ Jennifer Rimm, Comment, Booming Baby Business: Regulating Commercial Surrogacy in India, 30 U. PA. J. INT'L L. 1429, 1430 (2009).

${ }^{20}$ Browne-Barbour, supra note 8, at 434.

${ }^{21}$ Kari Points, Commercial Surrogacy and Fertility Tourism in India: The Case of Baby Manji, Case Studies in Ethics,THE KENAN INSTITUTE FOR ETHICS AT DUKE UNIVERSITY https://web.duke.edu/kenanethics/CaseStudies/BabyManji.pdf. ${ }^{22} I d$.
} 
In response, nations have modernized their laws to address the swift progress in this growing field. Certain countries have enacted permissive laws, while others have opted to install prohibitive legislation or simply not acknowledge surrogacy. ${ }^{23}$

Those who pursue fertility services abroad are driven by both economic and non-economic factors. ${ }^{24}$ The primary economic incentive is the reduced cost of surrogacy in foreign nations. ${ }^{25} \mathrm{In}$ the United States, gestational surrogacy costs between $\$ 110,000$ and $\$ 150,000{ }^{26}$ The surrogate's average compensation is approximately $\$ 25,000,{ }^{27}$ with the rest going towards agency fees, medical costs, legal fees, and incidental expenses such as travel. ${ }^{28}$ However, surrogacy costs are considerably lower in Eastern Europe and Southeast Asia. ${ }^{29}$ For example, gestational surrogacy in Ukraine costs approximately $\$ 45,000$, and the surrogate receives between $\$ 10,000$ and $\$ 15,000 .^{30}$ The average cost of gestational surrogacy declines further in India, where intended parents pay approximately $\$ 25,000$ and the surrogate earns $\$ 2,000$ to $\$ 10,000 .^{31}$

Various non-economic factors induce the pursuit of surrogacy arrangements abroad. ${ }^{32}$ For example, the desired treatment may be unavailable in an individual's home country. ${ }^{33}$ This may be due to lack of equipment, medical expertise, or socialized healthcare systems with long waiting lists to undergo a procedure. ${ }^{34}$ Furthermore, countries may prohibit reproductive services on moral

${ }^{23}$ Burpee, supra note 14 , at 310.

${ }^{24}$ Cherry, supra note 9 , at 260.

${ }^{25} \mathrm{Id}$.

${ }^{26} I d$.

${ }^{27} I d$.

${ }^{28}$ Deborah L. Cohen, Surrogate Pregnancies On Rise Despite Cost Hurdles, Reuters, Mar. 18, 2013, http://www.reuters.com/article/2013/03/18/us-parent-surrogate-idUSBRE92H11Q20130318[http://perma.cc/87SK$5 \mathrm{MWW}]$.

${ }^{29}$ Cherry, supra note 9, at 260.

${ }^{30} \mathrm{Id}$.

${ }^{31} I d$.

${ }^{32} I d$. at 261.

${ }^{33} I d$.

${ }^{34} I d$. 
grounds and implement discriminatory legislation. ${ }^{35}$ For example, certain countries forbid gays, lesbians, and single persons from pursuing surrogacy. ${ }^{36}$ Additionally, individuals travel to foreign countries that have methods of surveillance to observe surrogates and track their progress. ${ }^{37}$ Such methods include attaching surrogate living quarters to fertility clinics, where doctors can closely monitor the women and exercise control over their care. ${ }^{38}$

As the demand for surrogacy rose, nations that offered assisted reproductive technologies encountered domestic pressure relating to ethical, religious, and safety concerns. ${ }^{39}$ In response, some Westernized countries enacted regulatory legislation that limited access to treatment. ${ }^{40}$ The strict barriers included, but were not limited to, constraints on procedures such as implantation of multiple embryos; the exclusion of gays, lesbians, and single persons; and limitations on payments to gamete donors. ${ }^{41}$ As a result, surrogacy and assisted reproductive technology clinics emerged in less industrialized countries such as India, Thailand, and Mexico. ${ }^{42}$ Strict regulations created a “niche marke[t] of fertility tourism" to foreign couples struggling with infertility. ${ }^{43}$

\section{Surrogacy}

Surrogacy is divided into two distinct categories known as traditional surrogacy and gestational surrogacy. This Note focuses on gestational surrogacy. The surrogate's genetic contribution is the distinguishing factor between the two classifications. ${ }^{44}$ In traditional surrogacy

\footnotetext{
${ }^{35} I d$.

${ }^{36} I d$.

${ }^{37} \mathrm{Id}$.

${ }^{38} I d$.

${ }^{39}$ Kari Points, Commercial Surrogacy and Fertility Tourism in India: The Case of Baby Manji, Case Studies in Ethics, https://web.duke.edu/kenanethics/CaseStudies/BabyManji.pdf.

${ }^{40} \mathrm{Id}$.

${ }^{41} I d$.

${ }^{42} I d$.

${ }^{43} I d$.

${ }^{44}$ Rimm, supra note 19 , at 1436.
} 
arrangements, the surrogate contributes her egg and is therefore genetically related to the child she is carrying. ${ }^{45}$ The commissioning father (hereafter referred to as "intended father") supplies the sperm. ${ }^{46}$ In contrast, the surrogate has no genetic link to the child in a gestational surrogacy arrangement. $^{47}$

Gestational surrogacy is the newer of the two categories and was first reported in $1985 .^{48}$ Gestational surrogacy involves the surrogate mother carrying an embryo created from the genetic material of one or both of the commissioning parents (hereafter referred to as "intended parents"). ${ }^{49}$ If an intended parent is unable to supply his or her genetic material, he or she will utilize donor egg or sperm. ${ }^{50}$ Gestational surrogacy is considered "legally safer" than traditional surrogacy, because the child has no biological relation to the gestational surrogate ${ }^{51}$ Gestational surrogacy poses fewer hurdles to the establishment of legal parentage, as Western legal norms lean towards recognizing the genetic parent as the legal parent. ${ }^{52}$

The shift from traditional surrogacy towards gestational surrogacy was propelled by the Baby $M$ case decided by the New Jersey Supreme Court in 1986, where two families "ffought] over a baby who belonged to both of them." 53 In Baby M., the surrogate refused to return the child, born through traditional surrogacy, to the biological father and his wife. ${ }^{54}$ The embryo was created using the biological father's sperm and the surrogate's egg. ${ }^{55}$ The intended parents sued to

\footnotetext{
${ }^{45}$ Rimm, supra note 19 , at 1436.

${ }^{46} I d$.

${ }^{47} I d$.

${ }^{48}$ Burpee, supra note 14 , at 308.

${ }^{49}$ Rimm, supra note 19 , at 1437.

${ }^{50}$ Burpee, supra note 14 , at 308.

${ }^{51} I d .$.

${ }^{52}$ Id. 308-309.

53 Tamar Lewin, Coming to U.S. for Baby, and Womb to Carry It, N. Y. Times, July 5, 2014, http://www.nytimes.com/2014/07/06/us/foreign-couples-heading-to-america-for-surrogate-

pregnancies.html[https://perma.cc/N9WE-589E]

${ }^{54}$ In re Baby M, 109 N.J. 396, 415-16 (N.J.1988).

${ }^{55} I d$. at 412 .
} 
relinquish the surrogate's parental rights and sought to establish legal parentage in the biological father's wife. ${ }^{56}$ However, the New Jersey court ruled that the surrogate was the child's legal mother. ${ }^{57}$ The use of traditional surrogacy declined following the outcome of Baby $M .{ }^{58}$ Courts' inclination to establish legal parentage due to the genetic link and the accessibility of reproductive technology popularized gestational surrogacy. ${ }^{59}$

\section{Commercial Surrogacy vs. Altruistic Surrogacy}

Two categories of arrangements exist in regard to surrogate compensation: commercial and altruistic. ${ }^{60}$ In a commercial surrogacy arrangement, the surrogate "stands to gain financially" from giving birth to the child. ${ }^{61}$ The intended parents not only reimburse the surrogate for pregnancyrelated expenses, but also pay a fee for the surrogate carrying and birthing the child. ${ }^{62}$ Altruistic surrogacy arrangements differ from commercial surrogacy arrangements in that the surrogate is not paid for gestating and delivering the child. ${ }^{63}$ Nonetheless, the intended parents may still reimburse the surrogate for pregnancy-related medical expenses and living expenses in an altruistic surrogacy arrangement. ${ }^{64}$ The commercial and altruistic classifications are applicable to both gestational surrogacy arrangements and traditional surrogacy arrangements. ${ }^{65}$

Opponents of commercial surrogacy present two principal arguments. ${ }^{66}$ First, they assert that commercial surrogacy agreements are banned by public policy, even if all parties are in

\footnotetext{
${ }^{56} I d$. at 417.

${ }^{57}$ Id. at $450-51$.

${ }^{58}$ Burpee, supra note 14, at 308-09.

${ }^{59} \mathrm{Id}$.

${ }^{60} \mathrm{Id}$. at 309.

${ }^{61} \mathrm{Id}$.

${ }^{62} I d$.

${ }^{63} \mathrm{Id}$.

${ }^{64} \mathrm{Id}$.

${ }^{65} \mathrm{Id}$.

${ }^{66} \mathrm{Id}$. at 322.
} 
agreement. ${ }^{67}$ This perspective approximates commercial surrogacy to the sale of children and prostitution, emphasizing that surrogacy "is a form of labor that should never be exchanged for money." ${ }^{68}$ Second, opponents equate commercial surrogacy to "womb-rent[ing]," which would subject economically vulnerable women to exploitation. ${ }^{69}$ They contend that commercial surrogacy creates a market that forces poor women to succumb to financial pressures and coerces them into becoming surrogates. ${ }^{70}$ Commercial surrogacy opponents also argue that financially compensating surrogates will highlight class divisions, "lead[ing] to a society in which wealthy women use a surrogate because they are either too busy for pregnancy or do not want to ruin their figures." 71

Meanwhile, commercial surrogacy proponents maintain that surrogacy arrangements are "freely entered into by informed adults."72 Advocates stress that providing the surrogate with financial compensation will incentivize her to fulfill the terms of the agreement. ${ }^{73}$ This also bolsters the intended parents' confidence that the surrogate will maintain her end of the bargain. ${ }^{74}$ Proponents of this view believe that not paying a surrogate may cause her to feel that "she has more discretion to cancel or default on the contract." 75 Additionally, commercial surrogacy advocates assert that prohibiting the practice altogether will further the exploitation of women, as commercial surrogacy will be "forced underground" and surrogates will have "no legal recourse for abuse." 76

\footnotetext{
${ }^{67} \mathrm{Id}$.

${ }^{68} I d$.

${ }^{69} \mathrm{Id}$.

${ }^{70} \mathrm{Id}$.

${ }^{71} I d$. at 322.-23.

${ }^{72} \mathrm{Id}$. at 323.

${ }^{73} \mathrm{Id}$.

${ }^{74} \mathrm{Id}$.

${ }^{75} \mathrm{Id}$.

${ }^{76} \mathrm{Id}$.
} 


\section{B. Snapshot of Surrogacy Laws}

\section{The United States of America}

As nations that have legalized commercial surrogacy begin to impose legislative and/or costprohibitive restrictions, the link between surrogacy and fertility tourism becomes stronger than ever. The United States perceives surrogacy as a state law matter. ${ }^{77}$ Some states, such as California and Illinois, are very favorable toward commercial surrogacy. ${ }^{78}$ Meanwhile, states such as New York and Michigan not only ban the practice, but also effectuate civil and criminal sanctions upon those who participate in surrogacy arrangements. ${ }^{79}$ For example, the District of Columbia ${ }^{80}$ and New York $^{81}$ hold parties who enter into a commercial surrogacy contract civilly liable. Michigan imposes penalties such as a fine of up to $\$ 10,000$ and/or one year in prison for surrogates in a commercial surrogacy arrangement. ${ }^{82}$ Other states, such as Arizona, ${ }^{83}$ Indiana, ${ }^{84}$ North Dakota, ${ }^{85}$ and Louisiana ${ }^{86}$ prohibit both commercial and altruistic surrogacy. Rather than impose sanctions, they simply consider surrogacy contracts unenforceable. ${ }^{87}$

\footnotetext{
${ }^{77}$ Lisa C. Ikemoto, Article: Reproductive Tourism: Equality Concerns in the Global Market for Fertility Services, 27 LAW \& INEQ. 277, 297-98 (2009).

${ }^{78} I d$. at 298.

${ }^{79} \mathrm{Id}$.

${ }^{80}$ D.C. CODE $§ 16-402$ (2001).

${ }^{81}$ N.Y. DOM. REL. LAW $\S 123$ (McKinney 2010).

${ }^{82}$ MICH. COMP. LAWS ANN. $§ 722.859$ (West 2011).

${ }^{83}$ ARIZ. REV. STAT. ANN. § 25-218(A) (2007).

${ }^{84}$ IND. CODE ANN. § 31-20-1-1 (West 2008).

${ }^{85}$ N.D. CENT. CODE $\S 14-18-05$ (2009).

${ }^{86}$ LA. STAT. ANN. § 9:2713 (2005).

${ }^{87}$ Mortazavi, supra note 10, at 2259.
} 
Meanwhile, certain states "implicitly permit altruistic surrogacy" because their legislation explicitly prohibits only commercial surrogacy. ${ }^{88}$ For example, Washington ${ }^{89}$ and Louisiana ${ }^{90}$ consider commercial surrogacy arrangements as void against public policy, while Kentucky ${ }^{91}$ and Nebraska ${ }^{92}$ explicitly prohibit commercial surrogacy. Arkansas, ${ }^{93}$ Florida, ${ }^{94}$ Nevada, ${ }^{95}$ New Hampshire, ${ }^{96}$ New Mexico, ${ }^{97}$ and Virginia ${ }^{98}$ permit altruistic surrogacy arrangements that are heavily regulated. For example, both the New Hampshire ${ }^{99}$ and Florida ${ }^{100}$ statutes dictate that the intended parents must demonstrate a medical need for surrogacy. Regulations in other states vary in strictness.. ${ }^{101}$ New Hampshire requires the intended parents, the surrogate, and her husband to attend counseling prior to entering into a surrogacy arrangement. ${ }^{102}$ Florida does not have such a requirement, but the statute mandates specific qualifications such as the marital status of the parties (the intended parents must be married). ${ }^{103}$

${ }^{88} I d$. at $2259-60$.

${ }^{89}$ WASH. REV. CODE $\S 26.26 .240$ (2010).

${ }^{90}$ LA. STAT. ANN. § 9:2713 (2005).

${ }^{91}$ KY. REV. STAT. ANN. $\$ 199.590(4)$ (West 2006).

92 NEB. REV. STAT. ANN. § 25-21-200 (LEXISNEXIS 2008).

${ }^{93}$ ARK. CODE ANN. § 9-10-201 (2009).

${ }^{94}$ FLA. STAT. ANN. $\$ 742.15$ (West 2010).

${ }^{95}$ NEV. REV. STAT. $\$ 126.710$ (2011).

${ }^{96}$ N.H. REV. STAT. ANN. $\S \S 168-B: 1-: 32$ (LexisNexis 2010).

${ }^{97}$ N.M. STAT. ANN. § 40-11A-801 (2010).

98 VA. CODE ANN. §§ 20-156-165 (2008).

${ }^{99}$ Guide to State Surrogacy laws, American Progress, December 2007, https://www.americanprogress.org/issues/women/news/2007/12/17/3758/guide-to-state-surrogacy-laws/. [https://perma.cc/27PC-VAJU]

${ }^{100}$ FLA. STAT. ANN. $§ 742.15$ (West 2010).

${ }^{101}$ Mortazavi, supra note 10 , at 2260.

${ }^{102}$ N.H. REV. STAT. ANN. $\S \S 168-B: 8$ (LexisNexis 2010).

${ }^{103}$ FLA. STAT. ANN. § 742.15(1) (West 2010). 
Illinois, ${ }^{104}$ Texas, ${ }^{105}$ and Utah ${ }^{106}$ explicitly permit commercial surrogacy, and California implicitly allows commercial surrogacy. ${ }^{107}$ Texas ${ }^{108}$ and Utah's ${ }^{109}$ statutes recognize "reasonable remuneration paid to the surrogate." ${ }^{110}$ However, these statutes impose heavy restrictions on commercial surrogacy. ${ }^{111}$ For example, the Illinois Gestational Surrogacy Act of 1995 limits recognition of commercial surrogacy arrangements to gestational surrogacy. ${ }^{112}$ The statute also necessitates a demonstration of medical need, typically procured through a doctor's affidavit, and requires that intended parents and the gestational surrogate submit to a psychological evaluation. ${ }^{113}$ While California is legislatively silent on surrogacy, its case law indicates that California courts will enforce surrogacy agreements and establish legal parentage in the intended parents rather than the surrogate. ${ }^{114}$ States that expressly and implicitly permit commercial surrogacy are more popular destinations.

Surrogacy legislation has recently become a heavily debated issue in state legislatures. New Hampshire followed the example of pro-surrogacy states such as Illinois and California and, in 2014, enacted a law allowing commercial surrogacy. ${ }^{115}$ As states move towards legalizing surrogacy, more avenues become open to potential intended parents who can afford the cost of

104750 III. COMP. STAT. $\$ 47 / 5$ (2011).

105 TEX. FAM. CODE ANN. § 160.756 (West 2008).

${ }^{106}$ UTAH CODE ANN. § 78B-15-803 (LexisNexis 2008).

${ }^{107}$ See Mortazavi, supra note 10, at 2261.

108 TEX. FAM. CODE ANN. § 160.756 (West 2008).

${ }^{109}$ UTAH CODE ANN. § 78B-15-803 (LexisNexis 2008).

${ }^{110}$ Mortazavi, supra note 10, at 2261.

${ }^{111} I d$. at 2260.

112750 III. COMP. STAT. § 47/1 (2011).

${ }^{113} I d$.

${ }^{114}$ Mortazavi, supra note 10, at 2261. See Johnson v. Calvert, 851 P.2d 776, $783-87$ (Cal. 1993); Buzzanca v. Buzzanca, 72 Cal. Rptr. 2d 280, 291 (Cal. Ct. App. 1998).

115 Tamar Lewin, Coming to U.S. for Baby, and Womb to Carry It, N. Y. Times, July 5, 2014, http://www.nytimes.com/2014/07/06/us/foreign-couples-heading-to-america-for-surrogate-pregnancies.html [http://perma.cc/38N6-BWAY].. 
surrogacy in the United States. ${ }^{116}$ The number of babies born through surrogacy in the United States has tripled over the last ten years. ${ }^{117}$ In 2014 , over two thousand babies were born through gestational surrogacy in the United States. ${ }^{118}$

\section{India}

Individuals unable to pursue surrogacy in the United States have often utilized India as a cheaper alternative. ${ }^{119}$ Surrogacy became legal in India in 2002, and the industry has grown to be the "world's top destination for commercial surrogacy." ${ }^{120}$ The approximately three thousand clinics that provide surrogacy services to international clients in India generate more than $\$ 400$ million per year, and the number of clinics is increasing yearly by twenty-five percent. ${ }^{121}$ Indian surrogates give birth to approximately two thousand foreign babies each year." ${ }^{122}$ India's dominance is attributed to its affordability, high-quality private healthcare, English-speaking clinics, extensive number of women willing to participate in surrogacy, a "business climate that encourages the outsourcing of Indian labor," and the legality of commercial surrogacy. ${ }^{123}$ However, in 2013, India enacted a law restricting surrogacy only to heterosexual couples who have been married for a minimum of two years, and who come from countries where surrogacy is

\footnotetext{
${ }^{116} I d$.

${ }^{117} \mathrm{Id}$.

${ }^{118} I d$.

${ }^{119} \mathrm{Id}$.

${ }^{120}$ Kari Points, Commercial Surrogacy and Fertility Tourism in India: The Case of Baby Manji, Case Studies in Ethics, https://web.duke.edu/kenanethics/CaseStudies/BabyManji.pdf[http://perma.cc/X4C9-PXG6]

${ }^{121}$ Natalie Akoorie, Fertility Tourism: Couples Desperate for a Baby Heading Overseas, New Zealand Herald, April 15, 2014, http://www.nzherald.co.nz/lifestyle/news/article.cfm?c_id=6\&objectid=11238149[http://perma.cc/DEK3LTJN].

${ }^{122} \mathrm{Id}$.

${ }^{123}$ Kari Points, Commercial Surrogacy and Fertility Tourism in India: The Case of Baby Manji, Case Studies in Ethics, https://web.duke.edu/kenanethics/CaseStudies/BabyManji.pdf. [http://perma.cc/X4C9-PXG6]
} 
legal. ${ }^{124}$ This legislation bans single, same-sex, and unmarried individuals from pursuing surrogacy in India, as well as those "circumventing their home laws to have children."125

\section{Ukraine}

Ukraine is "quickly gaining traction" as an international surrogacy destination due to its liberal surrogacy laws. ${ }^{126}$ In Ukraine, only infertile, legally married heterosexual couples are permitted to pursue surrogacy, but the laws are otherwise surrogacy-friendly. ${ }^{127}$ Ukraine legally recognizes commercial surrogacy and is protective of intended parents' rights by granting them legal parentage upon the notarized written consent of the surrogate. ${ }^{128}$ Ukraine is home to numerous surrogacy clinics that "advertise the ... favorable policies toward intended parents as selling points." ${ }^{129}$ Statistics for the annual number of surrogacy arrangements are difficult to obtain, as no regulatory bodies exist to monitor surrogacy in Ukraine. ${ }^{130}$ A news source recently stated that in 2011, one hundred and twenty successful surrogacy pregnancies occurred in Ukraine. ${ }^{131}$ However, that number is believed to be much higher because surrogacy agencies are not required to report statistics to a governing body. ${ }^{132}$ Roughly half of the surrogacy arrangements in Ukraine involve international intended parents. ${ }^{133}$ In Ukraine, foreign intended parents spend approximately $\$ 30,000$ to $\$ 45,000$, with the surrogate receiving $\$ 10,000$ to $\$ 15,000 .{ }^{134}$ Ukraine is

\footnotetext{
${ }^{124}$ Jennifer Kirby, Fertility Tourism: Seeking Surrogacy in India, Thailand, Mexico. New Republic, December 10, 2013,http://www.newrepublic.com/article/115873/fertility-tourism-seeking-surrogacy-india-thailand mexico[http://perma.cc/DEK3-LTJN].

${ }^{125} \mathrm{Id}$.

126 Seema Mohapatra, Stateless Babies \& Adoption Scams: A Bioethical Analysis of International Commercial Surrogacy, 30 BERKELEY J. INT'L LAW. 412, 415 (2012).

${ }^{127} I d$. at 431.

${ }^{128} \mathrm{Id}$.

${ }^{129} \mathrm{Id}$. at 430 .

${ }^{130} \mathrm{Id}$. at $430-431$.

${ }^{131} \mathrm{Id}$.

${ }^{132} \mathrm{Id}$

${ }^{133}$ Mohapatra, supra note 126, at 431.

${ }^{134}$ Id.
} 
currently experiencing a "surplus of women who desire to be surrogates" and the costs of surrogates are expected to decrease as a result. ${ }^{135}$

\section{Russia}

India's strict restrictions and Ukraine's unfavorable treatment of unmarried persons and same-sex couples are popularizing other surrogacy destinations, such as Russia, Mexico, and Thailand. ${ }^{136}$ In Russia, gestational surrogacy is officially only legal for married heterosexual couples and single women. ${ }^{137}$ However, the law's position on same-sex couples, unmarried couples, and single persons "is not clearly spelled out," and as a result, "surrogacy is largely unrestricted."138 Therefore, unlike India and Ukraine, Russia does not expressly ban same-sex couples and single persons from pursuing surrogacy. ${ }^{139}$ Russian law does not acknowledge samesex marriage, and lesbian couples are treated as single women for purposes of surrogacy. ${ }^{140}$ Similar to Ukraine, Russia also protects intended parents' rights by granting legal parentage upon notarized written consent of the surrogate. ${ }^{141} \mathrm{With}$ the ongoing restrictions in India and Ukraine, "Russia is one such country that commentators have suggested foreign intended parents may travel to now because it is one of the countries where commercial surrogacy is legal and the cost appears to be relatively low."142

\footnotetext{
${ }^{135} I d$.

${ }^{136}$ Charles P. Kindregan and Danielle White, International Fertility Tourism: The Potential for Stateless Children in Cross-Border Commercial Surrogacy Arrangements, 36 SuFFOLK TRANSNAT'L L. REV. 527, 619 (2013).

${ }^{137}$ Id.

${ }^{138} \mathrm{Id}$.

${ }^{139} \mathrm{Id}$. at 620.

${ }^{140} I d$. at 619.

${ }^{141}$ Id. at 620.

${ }^{142}$ Id. at 619.
} 


\section{Mexico}

Mexico is another destination where international clients are "[flock]ing" to evade other countries' restrictive laws. ${ }^{143}$ Mexico does not address surrogacy, except in the state of Tabasco. ${ }^{144}$ Tabasco's civil code legalized gestational surrogacy in $1998 .{ }^{145}$ However, international surrogacy arrangements are considered relatively new in Tabasco, as foreign intended parents have only recently begun favoring countries such as Russia, Mexico, and Thailand over the United States, Ukraine, and India. ${ }^{146}$ Agencies were first based in Cancun, which is "already an established cent[er] of medical tourism." ${ }^{147}$ Many surrogacy programs, agencies, and clinics now exist throughout Mexico, where IVF treatment is permitted anywhere as long as the babies are born in Tabasco. ${ }^{148}$ The law allows payment for surrogates' medical and living expenses, but contains an “altruism requirement." 149 Nevertheless, commercial surrogacy persists, as this requirement is "an easily circumvented legal nuance." ${ }^{150}$ Agencies do not mention surrogate compensation on their websites or marketing materials, but calling the earnings "economic assistance" renders the payments permissible. $^{151}$

\section{Thailand}

\footnotetext{
143 Jennifer Kirby, Fertility Tourism: Seeking Surrogacy in India, Thailand, Mexico. New Republic, December 10, 2013,http://www.newrepublic.com/article/115873/fertility-tourism-seeking-surrogacy-india-thailandmexico[http://perma.cc/DEK3-LTJN].

144 Jo Tuckman, Surrogacy Boom in Mexico Brings Tales of Missing Money and Stolen Eggs, The Guardian, September 25, 2014, http://www.theguardian.com/world/2014/sep/25/tales-of-missing-money-stolen-eggssurrogacy-mexico[http://perma.cc/K4GB-V8XQ].

${ }^{145} I d$.

${ }^{146} I d$.

${ }^{147} \mathrm{Id}$.

${ }^{148} \mathrm{Id}$.

${ }^{149} \mathrm{Id}$.

150 Jo Tuckman, Surrogacy Boom in Mexico Brings Tales of Missing Money and Stolen Eggs, The Guardian, September 25, 2014, http://www.theguardian.com/world/2014/sep/25/tales-of-missing-money-stolen-eggssurrogacy-mexico[http://perma.cc/K4GB-V8XQ].

${ }^{151} I d$.
} 
Until recently, Thailand was another desirable destination for foreign clients because no laws against surrogacy existed. ${ }^{152}$ Therefore, surrogacy was de facto legal. ${ }^{153}$ Thailand's Medical Council banned commercial surrogacy in 1997, imposing restrictions such as "no compensation may be made" to the woman carrying the baby and that the surrogate must be "relative by blood of either party of the couple." 154 Nonetheless, Thailand experienced a boom of surrogacy-related tourism due to its large IVF market and restrictive legislation in other countries where commercial surrogacy is legal. ${ }^{155}$ Over the past few years, the use of surrogacy in Thailand has increased by fifty-four percent. ${ }^{156}$ Compared to the United States, surrogacy is also considerably more affordable, costing between $\$ 38,000$ and $\$ 50,000$. . $^{157}$

However, a series of surrogacy-related scandals erupted in the summer of 2014, such as an Australian couple's alleged abandonment of a baby with Down syndrome while taking home his healthy twin sister. ${ }^{158}$ As a result of the industry's rapid growth and the outrage created by the scandals, a draft bill banning and criminalizing commercial surrogacy passed its first reading with overwhelming support in November 2014. ${ }^{159}$ Thailand's Parliament passed the bill in February $2015,{ }^{160}$ which prevents foreigners from pursuing surrogacy in Thailand, forbids the "recei[pt] of any assets or benefits" stemming from a surrogacy arrangement[,] and seeks to punish violators

\footnotetext{
152 Trisha A. Wolf, Why Japan Should Legalize Surrogacy, 23 PAC. RIM L. \& POL'Y J. 461, 486 (2014).

153 Jennifer Kirby, Fertility Tourism: Seeking Surrogacy in India, Thailand, Mexico. New Republic, December 10, 2013, http://www.newrepublic.com/article/115873/fertility-tourism-seeking-surrogacy-india-thailandmexico[http://perma.cc/DEK3-LTJN].

154 Thai Parliament Votes to Ban Commercial Surrogacy Trade, BBC News Asia, November 28, 2014, http://www.bbc.com/news/world-asia-30243707[http://perma.cc/QL8K-C8JU].

155 Wolf, supra note 152 , at 486.

${ }^{156} \mathrm{Id}$.

${ }^{157} \mathrm{Id}$.

158 Thai Parliament Votes to Ban Commercial Surrogacy Trade, BBC News Asia, November 28, 2014, http://www.bbc.com/news/world-asia-30243707[http://perma.cc/QL8K-C8JU].

${ }^{159} \mathrm{Id}$.

160 Jonathan Head, Thailand's Crackdown on 'Wombs for Rent', BBC News, February 20, 2015, http://www.bbc.com/news/world-asia-31556597[http://perma.cc/R2QL-6LLD].
} 
with up to ten years in prison. ${ }^{161}$ The future of ongoing commercial surrogacy arrangements in Thailand is presently unclear, as the government seeking to pass the bill is composed of military junta members that took power through a coup d'état in May 2014. ${ }^{162}$ Additionally, Dr. Somsak Lolekha, a member of the Thai Medical Council, stated in a recent interview with the British Broadcasting Corporation that " $[\mathrm{w}] \mathrm{e}$ have no law enforcement ... [j] ust like drinking and driving. We have the law. But they never enforce it ... [t] hat is a weak point of Thailand." 163 According to a representative of Families Through Surrogacy in Australia, "[h]undreds of intended parents from Australia, or the US and European countries currently have pregnancies underway with Thai surrogates." 164 Foreign intended parents with present surrogacy arrangements in Thailand may now be caught in limbo. ${ }^{165}$

\section{Legal Considerations in Fertility Tourism}

\section{A. Difficulties in the Establishment of Legal Parentage}

The establishment of legal parentage poses problems in countries with lax and largely undefined laws. As a result, babies are caught in "legal limbo" due to the inconsistent surrogacy laws in various countries. ${ }^{166}$ For example, in Thailand, the surrogate and her husband are listed as the parents on the child's birth certificate. ${ }^{167}$ They must "renounce their parental rights" and the court subsequently must appoint a legal guardian. ${ }^{168}$ The risk of encountering difficulties

\footnotetext{
${ }^{161} I d$.

162 Thai Parliament Votes to Ban Commercial Surrogacy Trade, BBC News Asia, November 28, 2014, http://www.bbc.com/news/world-asia-30243707[http://perma.cc/QL8K-C8JU].

163 Jonathan Head, Thailand's Crackdown on 'Wombs for Rent', BBC News, February 20, 2015, http://www.bbc.com/news/world-asia-31556597[http://perma.cc/R2QL-6LLD].

164 Another Step to Ban Commerical Surrogacy, Nation, November 28, 2014, http://www.nationmultimedia.com/breakingnews/Another-step-to-ban-commercial-surrogacy30248827.html[http://perma.cc/PS4X-MDYS].

${ }^{165} \mathrm{Id}$.

${ }^{166}$ Mohapatra, supra note 126, at 415.

${ }^{167}$ Wolf, supra note 152 , at 486.

${ }^{168} \mathrm{Id}$.
} 
establishing legal parentage is therefore heightened. ${ }^{169}$ The absence of clear law regarding the enforceability of surrogacy contracts in Thailand also contributes to uncertainties involving legal parentage. ${ }^{170}$ Thai surrogacy agreements contain a provision declaring a "precommitment to transfer parental rights to intended parents." ${ }^{171}$ However, this "precommitment" fails to take into account that the surrogate is unable to predict her level of attachment to the baby at the time the agreement is executed. ${ }^{172}$ The "precommitment" also ignores the surrogate's potential desire to keep the baby, which is unforeseeable and can only be determined after the surrogate has gestated the baby for nine months. ${ }^{173}$

However, India, Ukraine, Russia, Mexico, and several states in the U.S. have enacted clear law regarding the establishment of legal parentage. Under Indian law, the intended parents are automatically recognized as the legal parents." ${ }^{174}$ Once the baby is born, the surrogate has no legal rights to the child. ${ }^{175}$ Ukraine has also codified the establishment of legal parentage. ${ }^{176}$ Ukraine's Family Code registers intended parents as the legal parents of the child "upon the notarized written consent of the surrogate." 177 The Russian Federation Family Code also permits the registration of intended parent(s) as the legal parents of the child upon the notarized written consent of the surrogate. ${ }^{178}$ The Tabasco Civil Code expressly allows the placement of the intended parents' names on the birth certificate. ${ }^{179}$ In the United States, various states uphold the legal parentage of

\footnotetext{
${ }^{169} \mathrm{Id}$.

${ }^{170} \mathrm{Id}$.

${ }^{171}$ Rimm, supra note 19 , at 1447.

${ }^{172} \mathrm{Id}$

${ }^{173} \mathrm{Id}$.

${ }^{174}$ Id. at 1446.

${ }^{175} \mathrm{Id}$.

${ }^{176}$ Mohapatra, supra note 126, at 431.

${ }^{177} \mathrm{Id}$.

${ }^{178} I d$.

${ }^{179}$ Jo Tuckman, Surrogacy Boom in Mexico Brings Tales of Missing Money and Stolen Eggs, The Guardian, September 25, 2014, http://www.theguardian.com/world/2014/sep/25/tales-of-missing-money-stolen-eggssurrogacy-mexico[http://perma.cc/K4GB-V8XQ].
} 
intended parents in surrogacy arrangements. For example, the Indiana Court of Appeals ruled in 2010 that Indiana paternity statutes grant legal parentage to the intended and genetic parents, unless it can be proven by clear and convincing evidence that the surrogate is the genetic mother of the child she carried. ${ }^{180}$ In 1993, the Supreme Court of California held that genetic parents involved in a gestational surrogacy agreement are considered the intended legal parents of the child carried by the surrogate. ${ }^{181}$ Additionally, the Illinois Gestational Surrogacy Act of 1995 grants legal parentage to the intended parents "immediately upon the birth of the child."182

\section{B. Citizenship Controversies: Stateless Children}

Citizenship controversies often arise as a result of inconsistent surrogacy laws. These hurdles appear in countries where the law is unclear or nonexistent in regard to the citizenship of children born through surrogacy. ${ }^{183}$ Out of the countries profiled in this Note, only the U.S. appears to possess clear laws regarding this issue. ${ }^{184}$ Children born in the U.S. receive birthright citizenship and may apply for a Green Card for their parents when they reach the age of twenty-one. ${ }^{185}$ This is one factor that draws a large amount of international intended parents to the U.S. ${ }^{186}$

Citizenship difficulties may result in a predicament where the child is considered “stateless." 187 This issue was popularized by the Indian case Baby Manji Yamada v. Union of India,

\footnotetext{
${ }^{180}$ Matter of Paternity and Maternity of Infant R., 922 N.E.2d 59 (Ind. Ct. App. 2010).

181 Johnson v. Calvert, 851 P.2d 776 (Cal. Sup. Ct. 1993).

182750 III. COMP. STAT. § 40/16 (2011).

${ }^{183}$ Mortazavi, supra note 10 , at 2285.

184 Tamar Lewin, Coming to U.S. for Baby, and Womb to Carry It, New York Times, July 5, 2014, http://www.nytimes.com/2014/07/06/us/foreign-couples-heading-to-america-for-surrogatepregnancies.html[http://perma.cc/N9WE-589E].

185 Id.

${ }^{186} \mathrm{Id}$.

${ }^{187}$ Kari Points, Commercial Surrogacy and Fertility Tourism in India: The Case of Baby Manji, Case Studies in Ethics, https://web.duke.edu/kenanethics/CaseStudies/BabyManji.pdf[http://perma.cc/X4C9-PXG6].
} 
where a Japanese couple entered into a gestational surrogacy arrangement with an Indian surrogate. ${ }^{188}$ The intended mother did not have parental rights, because unlike the intended father, she was not genetically related to the baby, Manji. ${ }^{189}$ However, the anonymous egg donor did not have any rights or responsibilities towards the child, the surrogate's parental rights had been contractually terminated, and the contract did not create any legally binding parental responsibilities in the intended mother. ${ }^{190}$ The intended father was unable to secure a Japanese passport or visa for Manji's return to Japan, because the Japanese Civil Code determines the child's nationality based on the birth mother's nationality. ${ }^{191}$ Manji was therefore not deemed a Japanese citizen. ${ }^{192}$ At the time, India's laws did not address commercial surrogacy, and required genetic parents to adopt their children born through surrogacy. ${ }^{193}$ However, the intended father was prevented from adopting Manji because of a 120-year-old law that forbade single men from adopting children. ${ }^{194}$ The intended father was also unable to secure an Indian passport for Manji because she did not have Indian parents. ${ }^{195}$ Manji was considered "stateless," and the case was referred to a national level. ${ }^{196}$ The court issued a "one-time" court order permitting Manji to receive an Indian birth certificate, thus granting her an Indian passport to travel to Japan. ${ }^{197}$

In 2008, The Gujarat High Court of India issued a similar "one-time" ruling in Jan Balaz v. Union of India. ${ }^{198}$ A German couple entered into a surrogacy arrangement with a surrogate mother

\footnotetext{
${ }^{188} I d$.

${ }^{189} \mathrm{Id}$.

${ }^{190} \mathrm{Id}$

${ }^{191} I d$.

${ }^{192} I d$.

${ }^{193}$ Kari Points, Commercial Surrogacy and Fertility Tourism in India: The Case of Baby Manji, Case Studies in Ethics, https://web.duke.edu/kenanethics/CaseStudies/BabyManji.pdf[http://perma.cc/X4C9-PXG6].

${ }^{194} \mathrm{Id}$.

${ }^{195} \mathrm{Id}$.

${ }^{196} \mathrm{Id}$.

${ }^{197}$ Id.

${ }^{198}$ Mortazavi, supra note 10, at 2275.
} 
to carry their twins. ${ }^{199}$ Although the children were genetically related to both intended parents, the Indian government withdrew previously issued Indian passports on grounds that the children did not have Indian parents. ${ }^{200}$ The German government refused to recognize the intended parents' legal parentage and grant the children passports because surrogacy is illegal in Germany. ${ }^{201}$ India eventually permitted one of the intended parents to adopt the children, granting them eligibility to receive a German visa and reside in Germany. ${ }^{202}$

Although certain countries may recognize the legal parentage of children born through surrogacy, citizenship difficulties emerge when these children return to their parents' home country. For example, a French court refused to register children born to a California surrogate as French citizens, despite a California court order establishing the intended parents' legal parentage ${ }^{203}$ While the court did not dispute the children's parentage or their right to travel to and reside in France, it denied them citizenship. ${ }^{204}$ Legal parentage recognition and the ability to travel are only part of the desired outcome; the denial of citizenship to children born through surrogacy creates significant complications.

The pursuit of surrogacy in Mexico, which is becoming a more popular destination with the recent legislative restrictions implemented in India and the prohibition introduced in Thailand, will likely trigger citizenship difficulties in the future. ${ }^{205}$ Since commercial surrogacy is only legal in the state of Tabasco, a risk exists that federal regulations may interfere with local surrogacy clinics

\footnotetext{
${ }^{199} I d$.

${ }^{200} I d$.

${ }^{201} I d$.

${ }^{202} I d$. at 2276.

${ }^{203} \mathrm{Id}$.

${ }^{204}$ Mortazavi, supra note 10, at 2276.
}

205 Where to Have Your Surrogacy Procedure, SENSIBLE SURROGACY http://www.sensiblesurrogacy.com/where-to-have-surrogacy/ [http://perma.cc/X8CX-HSL6].

(2014), 
in Tabasco. ${ }^{206}$ Additional concerns include the separation of the federal government, which issues passports and visas, from the state of Tabasco, which provides birth certificates. ${ }^{207}$

\section{RECENT LANDMARK DECISIONS}

The legal atmosphere surrounding the citizenship and parentage of children born to foreign surrogates is rapidly evolving in the European Union. ${ }^{208}$ In the summer of 2014, the European Court of Human Rights ("ECHR") ruled that France must recognize the citizenship of children born through surrogacy. ${ }^{209}$ France has banned surrogacy, and prior to this ruling, French authorities refused to enter these children into the country's registry of births, marriages, and deaths. ${ }^{210}$ This practice deprived children born through surrogacy of their citizenship, despite their genetic link to one or both parents. ${ }^{211}$ Previous court decisions ruled that entering these children into the French registry would legally condone surrogacy arrangements, which are void and unenforceable under France's laws. ${ }^{212}$ Children born through surrogacy were therefore stuck in "legal limbo." 213 Although they were residents of France, they were not recognized as citizens or as the legal offspring of their parents. ${ }^{214}$ This ruling extends to member countries of the ECHR where surrogacy is not recognized, such as Italy, Spain, and Germany. ${ }^{215}$ While these countries prohibit surrogacy, children born abroad are no longer in "limbo," as they are now granted legal recognition by their home country. ${ }^{216}$

\footnotetext{
${ }^{206} I d$.

${ }^{207} \mathrm{Id}$.

208 Michael Cook, Court Orders France to Recognise Surrogacy Children, BIOEDGE (Jul. 5, 2014) http://www.bioedge.org/index.php/bioethics/bioethics_article/11044 [http://perma.cc/WD2A-BSHN].

${ }^{209} \mathrm{Id}$.

${ }^{210} I d$.

${ }^{211} I d$.

${ }^{212} \mathrm{Id}$.

${ }^{213} \mathrm{Id}$.

214 Michael Cook, Court Orders France to Recognise Surrogacy Children, BIOEDGE, (Jul. 5, 2014), http://www.bioedge.org/index.php/bioethics/bioethics_article/11044 [\{https://perma.cc/WD2A-BSHN]

${ }^{215} \mathrm{Id}$.

${ }^{216} I d$.
} 
The ECHR decision has also prompted flexibility in the realm of establishing and solidifying legal parentage. ${ }^{217}$ In December 2014, the Federal Constitutional Court, Germany's highest court, issued a landmark ruling that permits the recognition of German intended parents as the legal parents of children born through surrogacy. ${ }^{218}$ The case involved a same-sex couple whose child was born to a California surrogate. ${ }^{219}$ The Superior Court in Placer County, California issued a court order ruling that the couple was the legal parents of the child. ${ }^{220}$ When they returned to Germany, the couple petitioned the Berlin courts to list them as the child's parents on the birth certificate. $^{221}$ This request was denied because the California surrogate was considered the child's mother under German law. ${ }^{222}$ The court reasoned that the California court order was null and void, as Germany considers surrogacy agreements to be against public policy. ${ }^{223}$

The couple appealed the decision to the Federal Supreme Court, which reversed the prior rulings. ${ }^{224}$ The court ordered the couple be registered as the child's legal parents, reasoning that the California court order is presumed valid under the comity principle and that German courts are not permitted to question a foreign court's ruling. ${ }^{225}$ Although German law prohibits surrogacy, the court emphasized that children born through surrogacy are entitled to have legal parents. ${ }^{226}$

\footnotetext{
${ }^{217} I d$.

218 Limited Win for Surrogacy, Gay Parenthood in Germany, DeUTSCHE WELLE (Dec. 19, 2014), http://www.dw.de/limited-win-for-surrogacy-gay-parenthood-in-germany/a-18142883 [http://perma.cc/Q7G3TU35].

${ }^{219}$ Id.

${ }^{220}$ Rich Vaughn, Children Born Abroad via Surrogacy Entitled to Legal Parents, German Court Rules, THE INTERNATIONAL FERTILITY LAW GROUP (Dec. 23, 2014), http://www.iflg.net/children-born-abroad-via-surrogacyentitled-to-legal-parents-german-court-rules/ [http://perma.cc/V3EZ-DE73].

${ }^{221}$ Id.

${ }^{222} \mathrm{Id}$.

${ }^{223}$ Id.

${ }^{224}$ Id.

${ }^{225} \mathrm{Id}$.

${ }^{226}$ Rich Vaughn, Children Born Abroad via Surrogacy Entitled to Legal Parents, German Court Rules, THE INTERNATIONAL FERTILITY LAW GROUP, (Dec. 23, 2014), http://www.iflg.net/children-born-abroad-via-surrogacyentitled-to-legal-parents-german-court-rules/.
} 
The court also reasoned that denying the couple's legal parentage would be an infringement of the child's human rights, because the surrogate is not recognized as the child's mother in her jurisdiction and is not prepared to take responsibility for the child. ${ }^{227}$

The ECHR decision, in conjunction with the "one-time" Indian court orders, illustrates a movement towards implementing protections to curb statelessness. ${ }^{228}$ Although the legalization of commercial surrogacy may not be in the foreseeable future, several countries that strictly prohibit surrogacy are nonetheless creating mechanisms to address issues arising from international surrogacy arrangements. ${ }^{229}$ As countries become more amenable to citizenship and parentage recognition, intended parents are incentivized to partake in cross-border surrogacy arrangements. These recent decisions forge a path to resolve legal issues involving parents and children, and will likely encourage the fertility industry's international growth.

\section{ETHICAL CONSIDERATIONS IN FERTILITY TOURISM}

\section{A. Paid ChILdBIRTH: Service OR ExPloitation?}

A notable consequence of cheaper surrogacy arrangements is the potentially exploitative nature of the industry. Surrogacy advertising in less industrialized countries mostly occurs in poverty-stricken locations. ${ }^{230}$ This elicits concern that surrogates only "enter these agreements out of economic necessity, without fully understanding the psychological and physical burdens that they stand to endure in the process." ${ }^{231}$ India's booming surrogacy industry has provided the opportunity to study surrogates' motivations to enter into an arrangement with international intended parents. One concern is the unequal bargaining power of the surrogates, demonstrated by

\footnotetext{
${ }^{227} \mathrm{Id}$.

${ }^{228}$ Mortazavi, supra note 10, at 2275.

${ }^{229} \mathrm{Id}$.

${ }^{230}$ Rimm, supra note 19 , at 1444.

${ }^{231}$ Id. at 1445.
} 
the flagrant contrast between what surrogates earn in the U.S. and how much they are compensated abroad. ${ }^{232}$ Student note author Jennifer Rimm found that "most individuals who participate as surrogates . . . are economically-deprived women who will admit to being attracted by the opportunity to earn as much as fifteen years of their income in nine months. ${ }^{, 233}$ She maintains that cheaper surrogacy costs abroad "merely exploit the diminished negotiating power of the potential surrogates" and worries that "[w]ithout regulation, international arrangements could become even more predatory, particularly with competition among women driving prices even lower."234 This phenomenon has also been observed in Thailand, where, although surrogates "are likely to be more educated and in a higher social strata than surrogates in India, they are still not in a position of power." 235

However, surrogacy arrangements can also provide life-changing advantages to Indian surrogates in poor areas because "the money they earn may allow them to buy a home for their family, start a small business or educate their own children." ${ }^{236}$ In many situations, the money is used to provide the surrogate's children with better education. ${ }^{237}$ Similarly, surrogates in Thailand mostly use the money to fund their education, satisfy their debts, or support their families. ${ }^{238} \mathrm{Dr}$. Nayna Patel, medical director of Akanksha Infertility Clinic in Gujarat, India, describes the benefits surrogates derive from engaging in commercial surrogacy:

A woman who becomes a surrogate is paid more money than she could earn in her entire lifetime. She is doing something that she believes is good and makes her proud - bearing a child for a couple desperate to start a family, while at the same time providing for her own family...It is easy for people in India and abroad who have

\footnotetext{
${ }^{232} I d$. at 1444.

${ }^{233} I d$.

${ }^{234} I d$. at 1445 .

${ }^{235}$ Wolf, supra note 152, at 487.

${ }^{236} I d$.

${ }^{237}$ Rimm, supra note 19 , at 1446.

${ }^{238}$ Wolf, supra note 152, at 487.
} 
never experienced infertility or poverty to say this is exploitation. But we are providing a service that profoundly changes people's lives for the better. ${ }^{239}$

Although Dr. Patel ensures that surrogates are not coerced or pressured by their family into entering a contract, she acknowledges the potential for exploitation. ${ }^{240}$ She recognizes that the booming industry necessitates further government supervision, and states that "[r]ules do need to be tighter to ensure women are not exploited in the future." 241

\section{B. Protection of Surrogate Rights}

Certain countries that have enacted laws allowing surrogacy have failed to account for the surrogate's rights. For example, Ukrainian law expressly protects the intended parents and the child, but does not mention the surrogate's rights. ${ }^{242}$ Should a surrogate wish to enforce her rights through a surrogacy contract, Ukrainian law is unclear in regard to the enforceability of such contracts. ${ }^{243}$ Legislation has been drafted to protect surrogates, but the government support for these bills has been nonexistent. ${ }^{244}$ Economically disadvantaged surrogates also lack access to legal counsel, as the surrogate would need to retain an attorney to draft or review the surrogacy agreement on her behalf. ${ }^{245}$ This option is not always financially feasible for surrogates. ${ }^{246}$ However, clinics are often unwilling to conduct embryo transfers without a surrogacy agreement in place. ${ }^{247}$ The disregard for surrogates' rights can result in dire consequences. For example, the discovery of a "baby-selling ring" by two prominent U.S. surrogacy attorneys has created

\footnotetext{
${ }^{239}$ Kari Points, Commercial Surrogacy and Fertility Tourism in India: The Case of Baby Manji, Case Studies in Ethics, https://web.duke.edu/kenanethics/CaseStudies/BabyManji.pdf [http://perma.cc/79ZA-366K].

${ }^{240} \mathrm{Id}$.

${ }^{241} I d$.

${ }^{242}$ Mohapatra, supra note 126, at 432.

${ }^{243} I d$.

${ }^{244} I d$.

${ }^{245} I d$. at 432.

${ }^{246} I d$.

${ }^{247} I d$. at $415-416$.
} 
controversy and compelled Ukraine to tread more cautiously in commercial surrogacy arrangements. $^{248}$

Countries where surrogacy is minimally regulated also lack a mechanism for enforcing surrogacy arrangements. ${ }^{249}$ As surrogacy contracts may be invalid in these nations, surrogates have no legal avenues to collect damages or obtain redress for violations of the surrogacy agreement. ${ }^{250}$ For example, surrogates' rights are surrounded by ambiguity in India. ${ }^{251}$ No legislative mechanism addresses surrogacy agreements, so the Indian Contract Act is applied in surrogacy disputes. ${ }^{252}$ Indian clinics follow unofficial guidelines, including limiting the surrogate's maximum age to forty, only accepting women deemed medically fit, and only permitting married women who have previously given birth to at least one child to become surrogates. ${ }^{253}$ However, these "unofficial rules" are not enforceable, and certain practices may be deemed questionable for the surrogate's health. ${ }^{254}$ For example, India does not limit the amount of times a woman can become a surrogate as long as she is healthy, without enacting mandatory standards to characterize what it means to be healthy for surrogacy purposes. ${ }^{255}$

Critics of commercial surrogacy legalization further the concern of the surrogate's unequal bargaining power. ${ }^{256}$ India's surrogacy framework is particularly scrutinized given the economic

\footnotetext{
${ }^{248}$ Mohapatra, supra note 126, at 415-416. See 'Baby-selling Ring' Lawyer Pleads Guilty, THE AssociATED PRESS, Aug. $\quad 10, \quad 2011, \quad$ http://www.cbc.ca/news/world/baby-selling-ring-lawyer-pleads-guilty-1.1114712. [http://perma.cc/EQP9-TNBG].

${ }^{249}$ Wolf, supra note 152 , at 486 .

${ }^{250} I d$.

${ }^{251}$ Vinita Lavania, Commercial Surrogacy in India: Exploitation or Mutual Assistance?, Infertility Awareness Association of Canada (Summer 2014), http://www.iaac.ca/en/commercial-surrogacy-in-india-exploitation-ormutual-assistance-4. [http://perma.cc/DEA7-GXEC].

${ }^{252} I d$.

${ }^{253} I d$.

${ }^{254} \mathrm{Id}$.

${ }^{255} \mathrm{Id}$.

${ }^{256}$ Cherry, supra note 9, at 264.
} 
vulnerability of Indian surrogates. ${ }^{257}$ Many surrogates are illiterate and poor, with a median family income of $\$ 60$ per month. ${ }^{258}$ One study reported that thirty-two out of forty-two women who volunteer to be gestational surrogates live at or below the poverty line. Indian surrogates earn fees that are equivalent to "approximately five years of family income." ${ }^{259}$ Certain scholars believe that this is coercive, as women are left with little choice but to adopt surrogacy as a strategy for survival. ${ }^{260}$ However, the global recession has altered the socioeconomic demographic of Indian surrogates. ${ }^{261}$ Educated, middle-class women are becoming gestational surrogates to supplement their family income or provide financial support when their husbands become unemployed. ${ }^{262}$

\section{Commodification of Human Life}

Some scholars have characterized India's commercial surrogacy industry as a "reproductive brothel." 263 Feminist theorist Andrea Dworkin coined this term to describe the "cultivation of surrogacy hostels." 264 Surrogates reside in these "hostels" throughout the entire surrogacy process, and are observed by doctors and clinic staff before and after the embryo transfer. ${ }^{265}$ Every aspect of their life is monitored, including food, medicine, and activities. ${ }^{266}$ Life in a "hostel" is described as follows:

[S] urrogates live together in a room lined with iron beds and nothing else. Husbands and family members are allowed to visit but not stay overnight. The women have nothing to do the whole day except

\footnotetext{
${ }^{257} \mathrm{Id}$.

${ }^{258} I d$.

${ }^{259} \mathrm{Id}$.

${ }^{260} I d$. at 277.

${ }^{261}$ Id. at 264.

${ }^{262}$ Cherry, supra note 9, at 264.

${ }^{263} \mathrm{Id}$.

${ }^{264} \mathrm{Id}$.

${ }^{265} \mathrm{Id}$.

${ }^{266}$ Commercial Surrogacy in India: Exploitation or Mutual Assistance?, Infertility Awareness Association of Canada, Summer 2014, http://www.iaac.ca/en/commercial-surrogacy-in-india-exploitation-or-mutual-assistance-4 [https://perma.cc/DEA7-GXEC].
} 
walk around the hostel, share their woes, experiences and gossip with the other surrogates while they wait for the next injection. ${ }^{267}$

Commercial surrogacy opponents believe the "hostel"-style living arrangement promotes the commodification of human life, where surrogates are heavily supervised in order to provide "the best product (i.e., baby)" to the commissioning intended parents. ${ }^{268}$ Critics worry that other countries will replicate the "reproductive brothel model," especially those nations where surrogates live at or below the poverty line, and where the laws favor intended parents. ${ }^{269}$ April J. Cherry, Professor of Law at Cleveland-Marshall College of Law, attributes the model to a 1950s60s movement in the United States, where pregnant teenage girls were moved from their homes to reside in "maternity homes" until their children were born. ${ }^{270}$

The "reproductive brothel" theory parallels commercial surrogacy to prostitution, where a woman "is easily reduced to what she sells." ${ }^{271}$ Proponents of this model assert that commercial surrogates are "fungible" and "simply nothing more than reproductive commodities." 272 Cherry evaluates these issues and determines that between the choices of regulation and prohibition, the appropriate response is prohibition. ${ }^{273}$ She argues that regulation will further commodify and degrade surrogates, thus perpetuating class and gender disparities. ${ }^{274}$

However, others assert that the prevalence of gestational surrogacy arrangements "diminish[es] the commodification frame." 275 The laws facilitating the establishment of legal

${ }^{267} \mathrm{Id}$.

${ }^{268}$ Cherry, supra note 9, at 264.

${ }^{269} I d$. at 265.

${ }^{270} \mathrm{Id}$.

${ }^{271} I d$. at 288.

${ }^{272} \mathrm{Id}$. at 257.

${ }^{273}$ Id. at 286.

${ }^{274}$ Cherry, supra note 9, at 286.

275 Transcript: What to Expect: Legal Developments and Challenges in Reproductive Justice, 15 CARDOZO J.L. \& GENDER 503, 536 (2009). 
parentage in countries such as the United States, India, Russia, Mexico, and Ukraine indicate that intended parents have a strong parental claim to their genetic offspring. ${ }^{276}$ Additionally, the media's lens is refocusing, and surrogates are increasingly being perceived as "performing a valuable service," rather than selling their child. ${ }^{277}$

\section{Stigmatization}

Stigmatization is another fate that befalls the parties in commercial surrogacy arrangements. ${ }^{278}$ The level varies among countries. Surrogacy is highly stigmatized in India, driven by the belief that poor women's bodies are commoditized and that motherhood is “immoral[ly] commerciali[zed]". ${ }^{279}$ Surrogates are not the only persons stigmatized in this process. ${ }^{280}$ India's largely patriarchal society attaches shame to infertile women, even if the infertility stems from the male. ${ }^{281}$ Womanhood is defined by a woman's "capacity to be a mother" in a patriarchal culture, and infertility is therefore perceived as a "curse."282 As a result, infertile couples in India favor assisted reproductive technologies such as gamete donation over adoption because they can be carried out in secret. ${ }^{283}$ While a surrogacy may not be as easily hidden, a preference may still exist for surrogacy over adoption due to the genetic link to the child. ${ }^{284}$

\footnotetext{
${ }^{276} I d$.

${ }^{277} I d$.

${ }^{278}$ Kindregan \& White, supra note 136, at 605.

${ }^{279} \mathrm{Id}$.

${ }^{280}$ Gregory Pence, Symposium, The Baby Market: Crossing Bodies, Crossing Borders: International Surrogacy Between the United States and India, 39 CUMB. L. REV. 14, 28 (2008).

${ }^{281}$ Id.

${ }^{282} \mathrm{Id}$. at $28-29$.

${ }^{283} I d$. at 28 .

${ }^{284}$ Id.
} 
Meanwhile, the social stigma is lower in Ukraine, where "surrogacy is no longer taboo."285 This is evidenced by the "availability and willingness" of women to become surrogate mothers. ${ }^{286}$ The acceptance is largely driven by the preference for genetically-related children through contemporary technology options rather than adoption if unable to conceive naturally. ${ }^{287}$ The technology is now available and readily accessible in Ukraine. ${ }^{288}$

Pop culture can manifest surrogacy stereotypes and stigmas, particularly in the United States. ${ }^{289}$ For example, in the 2008 film "Baby Mama," Tina Fey plays an accomplished executive who hires a working class girl (Amy Poehler) as her surrogate. ${ }^{290}$ While Fey's character is "a savvy, smart and well-to-do health-store-chain exec," Poehler's character is an "unemployed, deceitful wild child who wants easy money." ${ }^{291}$ However, evidence indicates that American surrogates perceive themselves as "performing a service of great social value for the benefit of others" ${ }^{292}$ and "value their ability to help others start families." 293

\section{The Great JuXtaposition: How Overly Stringent Regulation LEADS to \\ DEREgulation}

\section{A. InTENDEd Parent Discrimination AND ITS EFfects on Fertility TOURiSM}

\footnotetext{
${ }^{285}$ Claire Bigg \& Courtney Brooks, Ukraine Surrogacy Boom Not Risk-Free, RADIO FREE EUROPE RADIO LIBERTY (Jun. 9 , 2011), http://www.rferl.org/content/womb_for_hire_ukraine_surrogacy_boom_is_not_risk_free/24215336.html. [http://perma.cc/B5PX-JTR2].

${ }^{286}$ Kindregan \& White, supra note 136, at 605.

${ }^{287} I d$.

${ }^{288} I d$.

${ }^{289}$ Lorraine Ali, The Curious Lives of Surrogates, NEwsweEK, Mar. 29, 2008, http://www.newsweek.com/curiouslives-surrogates-84469 [https://perma.cc/3C3J-YJLT].

${ }^{290} I d$.

${ }^{291} I d$.

${ }^{292}$ Elizabeth S. Scott, Show Me the Money: Making Market in Forbidden Exchange: Surrogacy and the Politics of Commodification, 72 L. \& CONTEMP. PROB. 109, 138-39 (2009).

${ }^{293}$ Lorraine Ali, The Curious Lives of Surrogates, NEwSWEEK, Mar.29, 2008, http://www.newsweek.com/curiouslives-surrogates-84469.
} 
Although regulation establishes a framework and provides certain legal protections to the parties of a surrogacy agreement, it also functions as an exclusionary mechanism. These restrictions range from intended parent discrimination based on marital status, to discrimination based on sexual orientation. India enacted legislation in 2013 that restricts surrogacy to married heterosexual couples, therefore closing its doors to same-sex couples, unmarried couples, and single persons seeking to engage in surrogacy. ${ }^{294}$ Similarly, in Ukraine, surrogacy is restricted to infertile, heterosexual married couples. ${ }^{295}$

Russia currently has pending legislation imposing similar restrictions on commercial surrogacy. ${ }^{296}$ In 2014, Russian lawmakers drafted legislation that would prohibit the use of surrogacy by single men and women. Same-sex unions are illegal in Russia and same-sex couples are legally regarded as single men or women. ${ }^{297}$ The enactment of this legislation would therefore restrict same-sex couples from pursuing surrogacy in Russia. ${ }^{298}$ In contrast, the lack of strict regulation renders Russia a popular destination for surrogacy and also permits intended parents to bypass discriminatory legislation. The law is not clearly spelled out in regard to same-sex couples, unmarried couples, or single persons, so surrogacy is largely unrestricted in Russia. ${ }^{299}$ Gestational surrogacy is currently only legal for married couples and single women. ${ }^{300}$ Since Russian law does not recognize same-sex marriage, lesbian intended parents are considered single women for

\footnotetext{
${ }^{294}$ Jennifer Kirby, Fertility Tourism: Seeking Surrogacy in India, Thailand, Mexico, NEw RePUBLIC, December 10, 2013, http://www.newrepublic.com/article/115873/fertility-tourism-seeking-surrogacy-india-thailand-mexico. [http://perma.cc/B5PX-JTR2].

${ }^{295}$ Mohapatra, supra note 126, at 420.

296 Draft Russian Law Restricts Surrogacy For Single People, RUSSIA TODAY, Apr. 24, 2014, http://rt.com/politics/154496-russia-surrogacy-single-bill/. [http://perma.cc/ZZU3-SU2Q].

${ }^{297} I d$.

${ }^{298} I d$.

${ }^{299}$ Kindregan and White, supra note 136, at 619.

${ }^{300} I d$.
} 
surrogacy purposes." ${ }^{301}$ Nevertheless, such an approach perpetuates discrimination based on marital status. ${ }^{302}$ Russia's laws also render surrogacy entirely inaccessible to male same-sex couples. $^{303}$

The assortment of restrictions persuades intended parents to pursue surrogacy in destination countries with "lower prices and lax governmental regulations." 304 These countries often lack a legal framework for surrogacy, and certainly do not offer protections to the parties involved in a surrogacy arrangement. ${ }^{305}$ For example, the state of Tabasco in Mexico is becoming "the world's most dynamic new cent[er] of international surrogacy, fuelled by the tightening of restrictions in other countries." ${ }^{306}$ However, the "legal gr[a]y area" set forth by the circumvented altruism requirement signals the lack of regulation to which the parties in a commercial surrogacy arrangement are forced to resign. ${ }^{307}$

Mexico's lack of regulation poses a threat to all parties in a commercial surrogacy arrangement. ${ }^{308}$ Stories abound of agency mismanagement of client money, egg theft, psychological abuse of surrogates, and payment withholding. ${ }^{309}$ For example, Planet Hospital, a California-based surrogacy agency operating in Cancun, allegedly withheld reimbursements to intended parents after procedures were improperly conducted or incomplete. ${ }^{310}$ Planet Hospital

\footnotetext{
${ }^{301} \mathrm{Id}$.

302 Thai Parliament Votes to Ban Commercial Surrogacy Trade, BBC NEWS ASIA, Nov. 28, 2014, http://www.bbc.com/news/world-asia-30243707. [http://perma.cc/XMG9-BYCX].

${ }^{303} I d$.

${ }^{304}$ Rimm, supra note 19 , at 1436.

${ }^{305}$ Vinita Lavania, Commercial Surrogacy in India: Exploitation or Mutual Assistance?, INFERTILITY AWARENESS ASSOCIATION OF CANADA (Summer 2014), http://www.iaac.ca/en/commercial-surrogacy-in-india-exploitation-ormutual-assistance-4. [http://perma.cc/VGV4-UMJG].

306 Jo Tuckman, Surrogacy Boom in Mexico Brings Tales of Missing Money and Stolen Eggs, THE GUARDIAN, Sep. 25, 2014, http://www.theguardian.com/world/2014/sep/25/tales-of-missing-money-stolen-eggs-surrogacy-mexico. [http://perma.cc/5GEN-2N9P].

${ }^{307} \mathrm{Id}$.

${ }^{308} I d$.

${ }^{309} \mathrm{Id}$.

${ }^{310} I d$.
} 
declared involuntary bankruptcy in 2014, and is now the subject of a Federal Bureau of Investigation probe. ${ }^{311}$ Evidence also exists that, to the detriment of intended parents, "many surrogates are recruited without rigorous screening of their mental and physica[1] suitability." 312 For example, the newborn child of Thomas Chomko, an intended parent from New Jersey who pursued surrogacy in Mexico, spent three weeks in the intensive care unit battling an infection that likely "stemmed from inadequate screening of the surrogate before implantation." 313

In addition to Mexico, agencies have begun offering services in Nepal and Cambodia due to the recently enacted restrictions in Thailand and India. ${ }^{314}$ However, no legal surrogacy framework exists in Nepal and Cambodia, thus posing a great deal of risks to intended parents, surrogates, and children. ${ }^{315}$ According to the director of the Reproductive Health Association of Cambodia, surrogacy is not yet "common or explicitly legal, as "the law has yet to catch up to technology." 316

\section{B. Dangers Posed to Surrogates as a Consequence of Travel to Less Regulated}

\section{COUNTRIES}

As laws become more restrictive, potential intended parents develop a preference for cheaper and less regulated countries. ${ }^{317}$ Tighter restrictions have popularized other countries as surrogacy destinations, where inequality is rampant and the surrogates' safety is often

\footnotetext{
${ }^{311} I d$.

312 Jo Tuckman, Surrogacy Boom in Mexico Brings Tales of Missing Money and Stolen Eggs, THE GuARDIAN, September 25, 2014, http://www.theguardian.com/world/2014/sep/25/tales-of-missing-money-stolen-eggssurrogacy-mexico[http://perma.cc/5GEN-2N9P].

${ }^{313} I d$.

${ }^{314}$ Hilary Whiteman, Anxious Parents Fear for Babies as Military Tightens Surrogacy Laws, CNN, Aug. 19, 2014, http://www.cnn.com/2014/08/19/world/asia/thailand-surrogacy-laws-change/[http://perma.cc/9739-LKWB].

${ }^{315} I d$.

${ }^{316}$ Laignee Barron \& Mom Kunthear, 'Baby Factory' Suspect Living in Cambodia, PhNom Penh Post, Aug.18, 2014, http://www.phnompenhpost.com/national/\%E2\%80\%98baby-factory\%E2\%80\%99-suspect-living-cambodia. [http://perma.cc/J3EE-BY2H].

${ }^{317}$ Cherry, supra note 9, at 260.
} 
disregarded. ${ }^{318}$ People "enter into surrogacy agreements where the conditions are even riskier for all parties." ${ }^{\prime 319}$ As a result, the link between legalized surrogacy and fertility tourism becomes based on "the cultural and structural inequalities that create conditions in which some women's best economic opportunity is to undergo either egg retrieval, or pregnancy and childbirth for another." ${ }^{320}$

Consequently, traveling to countries where surrogacy is minimally regulated endangers the surrogate in various manners. ${ }^{321}$ The surrogate risks exploitation by a third party, such as an agency or a fertility clinic. ${ }^{322}$ Reports also exist that women have been forcibly trafficked to Thailand to work as surrogates. ${ }^{323}$ Another concern is lack of fully informed consent, as surrogates in poorer areas may be less educated, and obtaining a lawyer to represent them may not be financially feasible. ${ }^{324}$ Additional dangers include threats to surrogates' mental and physical health during the pregnancy and after the child's birth. ${ }^{325}$

\section{EXAMPLES OF DANGERS ENCOUNTERED IN COUNTRIES THAT LACK REgulation}

\section{a. MeXICO}

In Mexico, no legal recourse exists to enforce agencies' promises to surrogates. ${ }^{326}$ Should the intended parents change their minds during the pregnancy, the surrogate may find herself responsible for an unplanned child. ${ }^{327}$ While the intended parents' contract with the surrogate may

\footnotetext{
${ }^{318}$ Wolf, supra note 152 , at 483 .

${ }^{319} \mathrm{Id}$. at 481.

${ }^{320}$ Ikemoto, supra note 77, at 300.

${ }^{321}$ Rimm, supra note 19 , at 1461 .

${ }^{322} I d$.

${ }^{323} \mathrm{Id}$.

${ }^{324} I d$.

${ }^{325} \mathrm{Id}$.

${ }^{326}$ Jo Tuckman, Surrogacy Boom in Mexico Brings Tales of Missing Money and Stolen Eggs, THE GUARDIAN, Sep. 25, 2014, http://www.theguardian.com/world/2014/sep/25/tales-of-missing-money-stolen-eggs-surrogacy-mexico. [http://perma.cc/5GEN-2N9P]

${ }^{327} I d$.
} 
list the intended parents as the child's legal parents, the law provides no guidance or enforcement mechanism if the intended parents do not arrive for the child's birth. ${ }^{328}$ Additionally, agencies in Mexico control nearly all aspects of a surrogate's care, including the limitation of contact between parties. ${ }^{329}$ As a result, the surrogate has limited options to seek help should something go wrong. ${ }^{330}$ For example, when Planet Hospital was dismantled, the Planet Hospital owner created a new agency called Babies at Home. ${ }^{331}$ Claudia, a surrogate with the former Planet Hospital agency, was transferred to Babies at Home. ${ }^{332}$ During this transition, the former Planet Hospital surrogates moved to new apartments that lacked running water, electricity, and sufficient food. ${ }^{333}$ Claudia was unable to leave the apartments without the intended parents' authorization, and was not permitted to contact them through the agency due to the limitation on contact between parties. ${ }^{334}$ Claudia desperately contacted the intended parents through a Facebook message, who removed her from the care of Babies at Home and transferred her to a new agency. ${ }^{335}$

\section{b. Thailland}

In 2011, fifteen Vietnamese women were discovered in an apartment in Bangkok, Thailand. ${ }^{336}$ Seven of them were between twelve and thirty-four weeks pregnant, and two had recently given birth. ${ }^{337}$ They stated they had been lured there under the pretense of well-

\footnotetext{
${ }^{328} I d$.

${ }^{329} I d$.

${ }^{330} I d$.

${ }^{331} I d$.

332 Jo Tuckman, Surrogacy Boom in Mexico Brings Tales of Missing Money and Stolen Eggs, THE GUARDIAN, Sep. 25, 2014, http://www.theguardian.com/world/2014/sep/25/tales-of-missing-money-stolen-eggs-surrogacy-mexico. [http://perma.cc/5GEN-2N9P]

${ }^{333} \mathrm{Id}$.

${ }^{334} I d$.

${ }^{335} I d$.

${ }^{336}$ Richard Ehrlich, Taiwan Company Accused of Trafficking Vietnamese Women to Breed, WASHINGTON TIMES, Mar. 6, 2011, http://www.washingtontimes.com/news/2011/mar/6/thai-company-accused-traffick-vietnam-womenbreed/?page=all. [http://perma.cc/M5S2-88E5].

${ }^{337} I d$.
} 
compensated employment. ${ }^{338}$ When the women arrived to Thailand, their passports were seized by the Taiwan-based surrogacy agency Babe-101, and the women stated they were forced to become surrogates. ${ }^{339}$ The situation gave rise to potential criminal charges such as human trafficking, false imprisonment, and kidnapping. ${ }^{340}$ The scenario presented further issues, such as the parentage and citizenship of the children, the intended parents' rights to the children, and the pregnant surrogates' care. ${ }^{341}$ However, Thai authorities did not pursue charges against Babe- $101 .{ }^{342}$ Although the agency has shut down since the controversy, the doctor who supervised the medical aspects of the agency's surrogacies continues to practice at a "well-known" hospital in Bangkok. ${ }^{343}$

\section{c. INDIA}

The story of Anandhi embodies the dangers posed by laws that are overly stringent in some respects, but perilously lax in the protection of surrogate's rights. ${ }^{344}$ Anandhi, a "dirt poor" single mother of two from Chennai, India, volunteered to become a surrogate in hopes that the payment would enable her to establish a business. ${ }^{345}$ Despite delivering a healthy child, Anandhi only received $\$ 1,653.00$ of the $\$ 3,306.00$ that she was promised. ${ }^{346}$ A rickshaw driver who served as the middleman in the arrangement pocketed a fifty-percent cut of her earnings. Anandhi was also

\footnotetext{
${ }^{338} I d$.

${ }^{339} I d$.

${ }^{340}$ Richard Ehrlich, Surrogate Mothers Offered Everyone an "Efficient Embryo," FREE PRESS, Mar. 2, 2011, http://freepress.org/article/surrogate-mothers-offered-everyone-efficient-embryo. [http://perma.cc/Q69V-KBFL].

341 Patrick Winn, Underworld: Upending an Asian Baby Farm, GloBAL POST, Mar. 18, 2011, http://www.globalpost.com/dispatch/news/regions/asia-pacific/thailand/110310/thailand-surrogacy-humantrafficking?page=full. [http://perma.cc/WF4V-87U6].

342 Jonathan Head, Thailand's Crackdown on 'Wombs for Rent', BBC News, Feb. 20, 2015, http://www.bbc.com/news/world-asia-31556597. [http://perma.cc/L5E7-C9RB].

${ }^{343} I d$.

344 Shaikh Azizur Rahman, Indian Surrogate Mothers Suffer Exploitation, ALJAZEERA, Mar. 27, 2015, http://www.aljazeera.com/news/asia/2014/03/indian-surrogate-mothers-suffer-exploitation-

20143276727538166.html. [http://perma.cc/CAG8-4VLY].

$345 \mathrm{Id}$.

${ }^{346} I d$.
} 
denied free treatment by the hospital when she experienced post-delivery complications. ${ }^{347}$ The hospital refused to administer free treatment because she had already delivered the child. ${ }^{348}$

The Indian government's 2010 draft of the Assisted Reproductive Technologies Regulation Bill, which would "curb unregulated growth of ART clinics and better monitor existing clinics," has yet to become law. ${ }^{349}$ As a result, non-governmental organizations such as the Global Surrogate Mothers Advancing Rights Trust (“G-SMART”) emerged to protect the rights of poor women who become surrogates. ${ }^{350}$ G-SMART's advocacy includes eliminating middlemen, such as the rickshaw driver in Anandhi's case, who deliver prospective surrogates to Chennai hospitals. ${ }^{351}$ G-SMART also safeguards the interests of surrogates by ensuring that "surrogacy deals [are] transparent for all parties," and helps them obtain protections such as insurance. ${ }^{352}$ GSMART's success in curbing the exploitation of economically disadvantaged Indian surrogates demonstrates the need to instill protections for surrogates' rights in any form of regulatory legislation. ${ }^{353}$ However, India has advanced laws compared to countries such as Mexico, Thailand, and entirely unregulated countries such as Nepal and Cambodia (where intended parents are starting to travel due to overly restrictive laws in India, Russia, and Ukraine). ${ }^{354}$ The dangers surrogates experience in those countries are even greater than the ordeals exhibited in cases like Anandhi’s. ${ }^{355}$

\footnotetext{
${ }^{347} I d$.

${ }^{348} \mathrm{Id}$.

${ }^{349} \mathrm{Id}$.

350 Shaikh Azizur Rahman, Indian Surrogate Mothers Suffer Exploitation, ALJAZEERA, Mar. 27, 2015, http://www.aljazeera.com/news/asia/2014/03/indian-surrogate-mothers-suffer-exploitation20143276727538166.html. [http://perma.cc/CAG8-4VLY].

${ }^{351} \mathrm{Id}$.

${ }^{352} \mathrm{Id}$.

${ }^{353}$ Id.

${ }^{354} \mathrm{Id}$.

${ }^{355} \mathrm{Id}$.
} 


\section{Solutions}

Stringent commercial surrogacy regulation leads to deregulation. As surrogacy laws become more exclusionary, intended parents pursue surrogacy in unregulated countries, thus maximizing the risk posed to all parties involved in a surrogacy arrangement. This section surveys and evaluates the potential solutions to this dangerous consequence of strict surrogacy regulation.

\section{A. Domestic Regulation}

Scholars and practitioners advocate for regulation and establishment of clear law as solutions to the problems posed by the intersection of fertility tourism and legalized commercial surrogacy. John Weltman, an attorney who practices assisted reproductive law, proposes the establishment of a regulatory body for surrogacy agencies. ${ }^{356}$ Weltman notes that "[t]here are currently no requirements for establishing a surrogacy agency-anyone can start one- and there is no organization that oversees and regulates them." 357 Weltman expresses concerns that in the absence of surrogacy legislation in many states, agencies regulate themselves and create their own rules. ${ }^{358}$

Jennifer Rimm recommends that commercial surrogacy be restricted to non-profit agencies, charities, or governmental agencies to avoid potentially exploitative treatment of the surrogate. ${ }^{359}$ Rimm posits that this solution would "dramatically reduce the risk to surrogates that intermediaries introduce" and "protect potential surrogates ... from the black market industry that would develop if brokering surrogacy contracts was completely outlawed." ${ }^{360}$ Rimm also advocates for the

\footnotetext{
356 John Weltman, Comments on Recent International Surrogacy Stories, CIRCLE SuRRoGACY BLOG (Aug. 11, 2014), http://blog.circlesurrogacy.com/2014/08/11/comments-international-surrogacy-stories/[http://perma.cc/4VX62PBL].

${ }^{357} \mathrm{Id}$.

${ }^{358} I d$.

${ }^{359}$ Rimm, supra note 19 , at 1458.

${ }^{360} \mathrm{Id}$.
} 
enactment of comprehensive legislation that would impose minimum standards for payment. ${ }^{361}$ These standards would include the requirement that payment be put into escrow, minimal standards of care during pregnancy and after birth, and required compensation for permanent injuries that occur as a result of pregnancy and/or labor. ${ }^{362}$ While Weltman and Rimm's proposed forms of domestic regulation will certainly increase protection for surrogates' legal rights, they fail to address issues that arise on an international level. Commercial surrogacy is becoming increasingly more globalized with the number of individuals that pursue fertility tourism, and any regulatory mechanism needs to address citizenship difficulties and parentage issues that emerge from cross-border surrogacy arrangements.

\section{B. INTERNATIONAL REGULATION}

Lisa Ikemoto, Professor of Law at the University of California, suggests that international law should play a greater role in surrogacy. ${ }^{363}$ Ikemoto proposes to regulate surrogacy through the Hague Convention on Intercountry Adoption (hereafter referred to as "the Convention"). ${ }^{364}$ Ikemoto notes that "[t]he absence of law ... serves agencies and clinics well, but leaves surrogates, intended parents, and children unprotected." 365 Ikemoto believes that including surrogacy under the Convention will compel nations to ameliorate their laws. ${ }^{366}$ However, a Hague Special Commission on surrogacy convened in June 2010 and determined that the Convention was not an

\footnotetext{
${ }^{361}$ Id. at 1461 .

${ }^{362} I d$.

${ }^{363}$ Lisa Ikemoto, The Role of International Law for Surrogacy Must Be Expanded, NEW YoRK TIMES, Sep. 22, 2014, http://www.nytimes.com/roomfordebate/2014/09/22/hiring-a-woman-for-her-womb/the-role-of-international-lawfor-surrogacy-must-be-expanded [https://perma.cc/7N5B-F337].

${ }^{364} I d$.

365 Id.

${ }^{366} I d$.
} 
appropriate instrument to regulate international surrogacy. ${ }^{367}$ The members' chief concern was that the Convention does not address surrogate children and would further obscure their legal status. ${ }^{368}$ Attempts have been made to apply the Convention to international surrogacy disputes. ${ }^{369}$ Sarah Mortazavi, a student note author, argues that their fruitlessness illustrates the Convention's shortcomings in addressing surrogacy issues. ${ }^{370}$ Mortazavi presents the United Kingdom case $W$. $\&$ B. v. $H$ as an example, where a California couple entered into a traditional surrogacy agreement with a British surrogate. ${ }^{371}$ The intended parents obtained a court order in California that would grant them custody of the children after birth. ${ }^{372}$ However, the surrogate violated their agreement by giving birth in England and thereafter refusing to relinquish the babies. ${ }^{373}$ In the ensuing custody suit, the surrogate sought to apply the Convention, which would enforce the laws of the child's habitual residence. ${ }^{374}$ British law would grant legal parentage to the surrogate whereas California law would grant legal parentage to the intended parents. ${ }^{375}$ The Court considered the children to be habitual residents of England, as they had never lived in California. ${ }^{376}$ Under the Convention, British law would, therefore, be applicable. ${ }^{377}$ However, the British High Court deferred to the California court's order and ruled in favor of the intended parents. ${ }^{378}$ The Court abstained from applying the Convention, reasoning that the case was not compatible with the

\footnotetext{
${ }^{367}$ Mortazavi, supra note 10, at 2255.

${ }^{368}$ Id., FN 29.

${ }^{369} \mathrm{Id}$. at 2255.

${ }^{370} \mathrm{Id}$.

${ }^{371} I d$.

${ }^{372}$ Id.

${ }^{373}$ Mortazavi, supra note 10, at 2255.

${ }^{374} \mathrm{Id}$.

${ }^{375} I d$.

${ }^{376} \mathrm{Id}$.

${ }^{377} I d$.

${ }^{378} I d$.
} 
Convention's “original intent". ${ }^{379}$ The Court explained that the Convention was "not drafted with surrogacy in mind." 380

Mortazavi further contends that the Convention is not equipped to resolve major international surrogacy issues; namely commercial disputes and citizenship difficulties. ${ }^{381}$ First, Mortazavi maintains, the Convention "strongly discourages" compensation for adoption due to the semblance of providing payment for the mother's consent to relinquish her parental rights. ${ }^{382}$ Mortazavi is concerned that since surrogacy may include compensation, the Convention does not provide an adequate framework for dealing with commercial disputes. ${ }^{383}$ She states that strict adherence to the Convention and the prohibition of compensation might nullify a commercial surrogacy arrangement. ${ }^{384}$ She also believes that utilizing the Convention may lead to parentage issues that preclude intended parents from taking custody of their child. ${ }^{385}$

Mortazavi also asserts that the Convention "falls short when dealing with the statelessness of children." ${ }^{386}$ She notes that adoptions automatically entitle newborns to the citizenship of their birth mother, as her legal parentage is not "legally relinquished" until after the birth. ${ }^{387}$ However, in a surrogacy, the birth mother's parental rights may be terminated prior to the child's birth. ${ }^{388}$ In the event of conflicting surrogacy laws in the intended parents' home country, the child may be born without legal parents and considered "stateless". ${ }^{389}$ Mortazavi contends that the Convention

\footnotetext{
${ }^{379}$ Mortazavi, supra note 10 , at 2255.

${ }^{380} \mathrm{Id}$. at 2256.

${ }^{381} \mathrm{Id}$.

${ }^{382} \mathrm{Id}$.

${ }^{383} \mathrm{Id}$.

${ }^{384}$ Id.

${ }^{385}$ Mortazavi, supra note 10, at 2256.

${ }^{386} \mathrm{Id}$.

${ }^{387}$ Id.

${ }^{388} \mathrm{Id}$.

${ }^{389} \mathrm{Id}$.
} 
offers no guidance for scenarios where intended parents must return to their home country with their "stateless child." ${ }^{390}$ Mortazavi concludes that any potential international treaty regulating surrogacy must address the aforementioned issues. ${ }^{391}$

\section{CHILD'S BEST InTERESTS STANDARD}

Mortazavi advocates for the creation of international surrogacy legislation, reasoning that the "stark differences between states ... and . . between nations . . . highlight the imperative for uniform transnational rules." ${ }^{392}$ She suggests applying the child's best interests standard to guide any international surrogacy treaties. ${ }^{393}$ Mortazavi acknowledges that the standard is imprecise and lacks a universal definition. ${ }^{394}$ She cites various existing definitions of the child's best interests standard, and settles on the definition used in the Hague Conference Permanent Bureau's report for applying the best practices to the Convention, which includes the following factors:

[E]fforts to maintain or reintegrate the child in his/her birth family; a consideration of national solutions first (implementing the principle of subsidiarity); ensuring the child is adoptable, in particular, by establishing that necessary consents were obtained; preserving information about the child and his/her parents; evaluating thoroughly the prospective adoptive parents; matching the child with a suitable family; imposing additional safeguards where necessary to meet local conditions; providing professional services. 395

This approach, which would permit the child's best interests standard to supersede national policy, is another form of regulation that would benefit rather than curb fertility tourism. ${ }^{396}$ Applying the child's best interests standard would implement safeguards to protect intended parents from citizenship and parentage issues. ${ }^{397}$ Mortazavi argues that 'deferring to the child's-

\footnotetext{
${ }^{390} I d$.

${ }^{391}$ Mortazavi, supra note 10, at 2256.

${ }^{392} I d$. at 2257.

${ }^{393} I d$.

${ }^{394} \mathrm{Id}$

${ }^{395} \mathrm{Id}$.

${ }^{396} I d$.

${ }^{397} I d$.
} 
best-interest standard may necessitate countries being flexible when granting citizenship, issuing exit permits, or awarding custody based on the best outcome for the child, not the nation." 398 The resolution of these prevalent issues would promote fertility tourism by offering protections to intended foreign parents in the realm of legal parentage and immigration. ${ }^{399}$

\section{A COMPREHENSIVE APPROACH}

What distinguishes Mortazavi's approach from that of other scholars and practitioners is that it also advocates for a comprehensive solution that addresses the negative consequences of strict regulation, such as the one identified in this Note. Mortazavi calls for legalized commercial surrogacy to be accompanied by several requirements: the assurance of legal parentage and citizenship of children born through surrogacy, the prioritization of surrogates' health and wellbeing, and the shielding of intended parents from discrimination based on their marital status and/or sexual orientation. ${ }^{400}$

Mortazavi suggests a step-by-step approach to achieve this goal. ${ }^{401}$ First, individual state legislatures, national governments, and international instruments such as the Hague Convention must enact laws directing potential intended parents to establish that they are fit parents. ${ }^{402}$ Once they are deemed fit and receive authorization, the intended parents' home countries should allow them to apply to nations where commercial surrogacy is legal. ${ }^{403}$ These nations must recognize the intended parents' establishment of legal parentage, place funds in legally monitored accounts, and screen surrogates and match them with intended parents based on not only "their similar views on

\footnotetext{
${ }^{398}$ Mortazavi, supra note 10, at 2258.

${ }^{399} \mathrm{Id}$.

${ }^{400} \mathrm{Id}$.

${ }^{401}$ Mortazavi, supra note 10, at 2290.

${ }^{402}$ Id.

${ }^{403} I d$.
} 
termination and selective reduction, but also for their financial stability and their thoughtful motivations for moving forward with a surrogacy journey." ${ }^{" 404}$

Some of these countries that legalize surrogacy already follow certain regulatory practices proposed by Mortazavi. For example, Russian legislation delineates surrogacy procedures followed by IVF clinics. ${ }^{405}$ Russian physicians are only permitted to transfer up to three embryos during each embryo transfer. ${ }^{406}$ This limitation is in stark contrast with India's laws, where clinics are largely unregulated and impose no limit on the number of embryos implanted in a surrogate at a time ${ }^{407}$ Russian law also explicitly permits a surrogate to "get remuneration for her services and be compensated for the actual expenses as well." 408 Although no regulatory body exists in Russia to provide permission to enter into a gestational surrogacy arrangement, Russian law imposes certain requirements. ${ }^{409}$ For example, intended parents must indicate a medical need for surrogacy, such as "repeatedly failed IVF attempts when high quality embryos were repeatedly obtained and their transfer was not followed by their pregnancy." 410 The surrogate is also prohibited from having any relation to the intended parents. ${ }^{411}$

However, Mortazavi's proposed recommendations are not without flaws. The creation of international surrogacy legislation is problematic because it may breach other nations' sovereignty in establishing their own public policy. ${ }^{412}$ Additionally, some countries may not wish to

\footnotetext{
${ }^{404}$ John Weltman, Comments on Recent International Surrogacy Stories, CIRCLE SuRROGACY BLOG, (Aug. 11, 2014), http://blog.circlesurrogacy.com/2014/08/11/comments-international-surrogacy-stories/.

${ }^{405}$ Kindregan \& White, supra note 136, at 621.

${ }^{406} I d$.

${ }^{407} I d$.

${ }^{408} I d$.

${ }^{409} I d$.

${ }^{410} \mathrm{Id}$. at 620.

${ }^{411}$ Kindregan \& White, supra note 136, at 621.

${ }^{412}$ Mortazavi, supra note 10, at 2257.
} 
compromise a portion of their sovereignty to enter into a treaty. ${ }^{413}$ Enforcement issues may arise in dualist nations such as the United States, where international law is separate from domestic law. ${ }^{414}$ In order to transpose a treaty into domestic law, the United States will need to enact federal legislation. ${ }^{415}$ Not only will this be a lengthy process; it may also create federalism issues because family law is typically "within the purview of the state." ${ }^{116}$ Nonetheless, certain treaties such as the Convention on the Rights of the Child have been signed and ratified by almost all countries. ${ }^{417}$ This indicates that states may be willing to forego part of their sovereignty to achieve a common objective.

While Mortazavi's approach contains potential difficulties, no perfect solution exists to resolve the issues that arise in international commercial surrogacy. ${ }^{418}$ Nations must comprehensively address the ethical and legal aspects of surrogacy on a global level, and any solution should implement the ideas that Mortazavi advances.

\section{CONCLUSION}

Stringent regulation in countries that permit commercial surrogacy proliferates travel to unregulated countries that lack protective safeguards. As these nations adopt stricter surrogacy laws, intended parents flock to countries without a framework to protect the rights of parties involved in a surrogacy arrangement. To prevent this phenomenon, countries that permit and regulate commercial surrogacy must take a step further to offer legal protections to each party.

\footnotetext{
${ }^{413}$ Michael Mansell, A Treaty as a Final Settlement?, speech delivered at Murdoch University Treaty -- Advancing Reconciliation Conference, Perth, (June 27, 2002) <www.treaty.murdoch.edu.au/ Conference\%20Papers/Michael\%20Mansell.htm> (August 16, 2004). ("the nature of a treaty involves compromise."). ${ }^{414}$ Id.

${ }^{415}$ Martin Rogoff, Application of Treaties and the Decisions of International Tribunal in the United States and France: Reflections on Recent Practice, 58 ME. L. REV. 405, 448 (2006). ("The [international] agreement must be properly incorporated into the domestic legal order before a domestic court can apply it.").

${ }^{416}$ Mortazavi, supra note 10, at 2257.

417 Convention on the Rights of the Child, Nov. 20, 1989, 1577 U.N.T.S. 3.

${ }^{418}$ Cherry, supra note 9, at 259.
} 
They must recognize the legal parentage and citizenship of children born through surrogacy, establish a regulatory framework that safeguards the rights of surrogate mothers, and protect intended parents from discrimination based on their marital status and/or sexual orientation. 